\title{
Pengaruh Penerapan Prinsip-Prinsip Good Governance dan Budaya Organisasi terhadap Kinerja Keuangan
}

\author{
I Gede Dhyana Putra1 \\ Fakultas Ekonomi dan Bisnis \\ Universitas Udayana, Indonesia
}

\author{
I G. A. M. Asri Dwija Putri² \\ Fakultas Ekonomi dan Bisnis \\ Universitas Udayana, Indonesia
}

\begin{abstract}
Surel : putradhyana@gmail.com
ABSTRAK

Penelitian ini bertujuan menguji pengaruh penerapan prinsipprinsip good governance dan budaya organisasi terhadap kinerja keuangan. Penelitian ini dilakukan pada Lembaga Perkreditan Desa (LPD) di Kabupaten Gianyar. Metode pengambilan sampel menggunakan proportionate stratified random sampling. Jumlah sampel penelitian ini adalah sebanyak 25 LPD yang tersebar di setiap kecamatan di Kabupaten Gianyar. Pengumpulan data dilakukan melalui pendekatan survey dengan metode kuesioner dan juga pengumpulan data berupa laporan keuangan LPD tahun 2018. Teknik analisis data yang digunakan adalah uji Analisis Regresi Linear Berganda. Berdasarkan hasil pengujian, ditemukan terdapat pengaruh positif dari penerapan prinsipprinsip good governance dan budaya organisai terhadap kinerja keuangan LPD di Kabupaten Gianyar.
\end{abstract}

Kata Kunci: Good Governance; Budaya Organisasi; Kinerja Keuangan; Lembaga Perkreditan Desa.

\section{Effect of Application of Good Governance Principles and Organizational Culture on Financial Performance}

\section{ABSTRACT}

This study aims to examine the effect of applying the principles of good governance and organizational culture on financial performance. This research was conducted at the Village Credit Institution (LPD) in Gianyar Regency. The sampling method uses proportionate stratified random sampling. The number of samples of this study were 25 LPDs spread in each district in Gianyar Regency. Data collection was carried out through a survey approach with a questionnaire method and also data collection in the form of LPD financial statements in 2018. The data analysis technique used was the Multiple Linear Regression Analysis test. Based on the test results, it was found that there was a positive influence from the application of good governance principles and organizational culture to the financial performance of LPD in Gianyar Regency.

Keywords: Good Governance; Organizational Culture; Financial Performance; Village Credit Institutions.

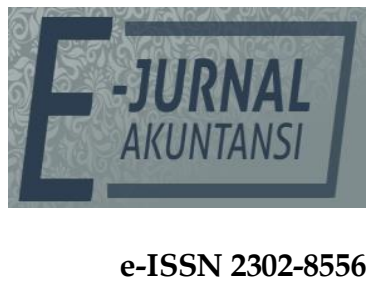

Vol. 30 No. 8

Denpasar, Agustus 2020 Hal. 2078-2088

DOI:

10.24843/EJA.2020.v30.i08.p14

PENGUTIPAN:

Putra, I G. D. \& Putri, I G. A. M.

A. D. (2020). Pengaruh Penerapan Prinsip-Prinsip Good Governance dan Budaya

Organisasi terhadap Kinerja Keuangan. E-Jurnal Akuntansi, 30(8), 2078-2088

RIWAYAT ARTIKEL:

Artikel Masuk: 12 Mei 2020 Artikel Diterima: 20 Juli 2020

Artikel dapat diakses : https://ojs.unud.ac.id/index.php/Akuntansi/index 


\section{PENDAHULUAN}

Pelaksanaan pengelolaannya LPD mewajibkan penerapan prinsip-prinsip Good Governance atau tata kelola perusahaan sesuai dengan yang tertulis dalam Pedoman Umum Good Corporate Governance oleh Komite Nasional Kebijakan Governance (KNKG) yang mewajibkan setiap organisasi yang sahamnya telah tercatat di bursa efek, perusahaan Negara, perusahaan daerah, perusahaan yang menghimpun dan mengelola dana masyarakat luas, serta perusahaan yang mempunyai dampak luas terhadap lingkungan untuk menerapkan praktik good corporate governance (KNKG, 2006). Good governance yang baik dapat membantu terciptanya hubungan yang kondusif antara elemen-elemen dalam suatu organisasi dalam rangka meningkatkan kinerja organisasi tersebut (Soraya, 2018). Selain berpengaruh terhadap kinerja organisasi, penerapan good governance juga dapat meningkatkan kinerja keuangan karena penerapan good governance dapat mengurangi resiko akibat dari tindakan pengelolaan yang cenderung menguntungkan diri (Puspitha \& Sujana, 2016) sendiri (Puspitha, 2015).

Kinerja keuangan adalah prestasi kerja yang telah dicapai oleh suatu entitas dalam periode tertentu yang tertuang dalam laporan keuangan (Sri, 2010). Kinerja keuangan merupakan salah satu alat ukur yang digunakan oleh para pengguna laporan keuangan dalam menentukan sejauh mana kualitas perusahaan tersebut. Pengukuran kinerja keuangan dapat dilakukan dengan menggunakan berbagai rasio keuangan, seperti rasio likuiditas, rasio profitabilitas, rasio solvabilitas, rasio aktivitas maupun rasio pasar (Prasinta, 2012). Krismaya (2014) menyatakan bahwa kinerja keuangan dapat dikatakan baik apabila pada saat penilaian keseluruhan aspek keuangan berpredikat sehat. Menurut Surat Keputusan BPD Bali Nomor 0193.02.10.2007.2, pada dasarnya tingkat kesehatan LPD dinilai melalui pendekatan kuantitatif yang berdasarkan pada empat faktor, antara lain: 1) permodalan (capital), 2) kuantitas aktiva produktif (asset), 3) rentabilitas (earning), dan 4) likuiditas (liquidity).

Prinsip-prinsip good governance yang diterapkan dalam pengelolaan LPD akan menjadi acuan LPD dalam mengambil berbagai langkah dan keputusan yang memungkinkan pengelolaan LPD menjadi lebih baik, sehingga juga dapat meningkatkan kinerja keuangan LPD. Adapun prinsip-prinsip good governance terdiri dari transparency, accountability, responsibility, independence, dan fairness. Dominikus (2014) menyatakan bahwa penerapan corporate governance tidak hanya bergantung pada prinsip-prinsip dan peraturan yang ada, namun juga bergantung pada integritas dari sumber daya manusia yang ada dalam perusahaan tersebut. Etika dan budaya kerja, serta prinsip-prinsip kerja profesional turut memegang peranan penting dalam penerapan corporate governance.

Sebagai suatu entitas yang telah mengimplementasikan tata kelola perusahaan yang baik, tentunya LPD memiliki pedoman untuk mengatur sikap dan tingkah laku karyawannya, seperti budaya perusahaan sebagai rumusan dalam karakteristik tertentu pada penerapan good governance untuk menjadi landasan menjalankan perusahaan tersebut. Budaya perusahaan tersebut dapat dijadikan acuan bagi karyawan dalam melaksanakan kewajibannya bertugas di LPD. 
Suatu budaya organisasi akan memengaruhi kinerja diawali dari input organisasi yang meliputi inovasi dan pengembangan risiko, perhatian ke rincian, orientasi hasil, orientasi orang, orientasi tim, keagresifan, dan kemantapan yang kemudian dipersepsikan sebagai budaya organisasi yang akan menjadi sebuah kekuatan yang tinggi atau rendah yang berdampak pada tingkat kinerja dan kepuasan karyawan (Robbins \& Jugde, 2008) Semakin baik budaya organisasi dalam suatu perusahaan maka kinerja perusahaan tersebut akan semakin baik pula. Penelitian ini memilih budaya organisasi sebagai variabel tetap, karena budaya organisasi memiliki pengaruh yang besar terhadap perilaku anggotaanggotanya dalam mewujudkan strategi organisasi dalam rangka meningkatkan kinerja keuangan perusahaan.

Kabupaten Gianyar termasuk salah satu kabupaten dengan jumlah aset LPD yang tinggi di Bali. Kabupaten Gianyar telah mencatat total asset seluruh LPD mencapai Rp 4,6 trilun hingga bulan Desember 2018. Berdasarkan data Lembaga Pemberdayaan-Lembaga Perkreditan Desa (LP-LPD) pencapaian laba cukup baik hingga Desember 2018 mencapai Rp 119 miliar. Di balik pertumbuhan aset dan pertumbuhan laba LPD di Kabupaten Gianyar yang cukup tinggi, dari 270 LPD yang ada di Kabupaten Gianyar terdapat 7 LPD dalam kategori tidak sehat, 32 LPD dalam kategori kurang sehat, serta sebanyak 29 LPD tidak beroperasional. Sedangkan sebanyak 162 LPD berada dalam kategori sehat, dan 40 LPD berada dalam kategori cukup sehat. Kegagalan tersebut sebagian besar dapat disebabkan karena terjadinya kesalahan tata kelola di dalam LPD tersebut.

Penelitian sebelumnya mengenai pengaruh good governance terhadap kinerja keuangan telah dilakukan oleh Mahaendrayasa \& Putri (2017) yang menyatakan bahwa variabel transparansi dan responsibilitas berpengaruh positif tidak signifikan pada kinerja keuangan dan variabel akuntabilitas, independensi dan kewajaran berpengaruh positif signifikan terhadap kinerja keuangan LPD di Kota Denpasar. Hasil penelitian dari Pradnyaswari (2016) menyatakan bahwa prinsip-prinsip GCG berpengaruh positif terhadap kinerja keuangan koperasi di Kabupaten Klungkung. (Puspitha \& Sujana, 2016) dalam penelitiannya menyebutkan bahwa terdapat pengaruh positif antara GCG terhadap kinerja keuangan berbasis balance scorecard dan variabel budaya organisasi memperkuat pengaruh prinsip-prinsip GCG terhadap kinerja keuangan yang berbasis balance scorecard. Soraya \& Suardana (2018) menyatakan bahwa prinsip-prinsip GCG berpengaruh positif terhadap kinerja keuangan BPD Bali dan budaya organisasi dapat memperkuat hubungan prinsip-prinsip GCG pada kinerja keuangan BPD Bali.

Penerapan prinsip-prinsip good governance yang konsisten dan berkelanjutan merupakan salah satu faktor penting yang dapat meningkatkan kinerja dan meningkatkan nilai perusahaan (Gunawan et al., 2014)). Good corporate governance berhubungan dengan kinerja organisasi dalam pengambilan keputusan yang lebih baik, manajemen aset yang efektif, keunggulan kompetitif, dan peningkatan tingkat kepercayaan pada perusahaan (Adebayo et al., 2014).

Penelitian sebelumnya mengenai pengaruh Good Governance terhadap kinerja keuangan telah dilakukan oleh Mahaendrayasa \& Putri (2017) yang menyatakan bahwa variabel transparansi dan responsibilitas berpengaruh positif 
tidak signifikan pada kinerja keuangan dan variabel akuntabilitas, independensi dan kewajaran berpengaruh positif signifikan terhadap kinerja keuangan LPD di Kota Denpasar. Hasil penelitian dari Pradnyaswari (2016) menyatakan bahwa prinsip-prinsip GCG berpengaruh positif terhadap kinerja keuangan koperasi di Kabupaten Klungkung.

Ingdanata (2018) yang meneliti mengenai pengaruh good corporate governance dan love of money terhadap kinerja keuangan Bank Perkreditan Rakyat di Kota Denpasar menemukan bahwa terdapat pengaruh positif antara good corporate governance pada kinerja keuangan Bank Perkreditan Rakyat di kota Denpasar. Hasil yang serupa juga ditemukan oleh Soraya \& Suardana (2018)yang menemukan bahwa good governance memiliki pengaruh yang positif terhadap kinerja keuangan BPD Bali. Dengan demikian, hipotesis yang dapat dirumuskan adalah sebagai berikut:

$\mathrm{H}_{1}$ : Penerapan Good Governance berpengaruh positif pada kinerja keuangan Lembaga Perkreditan Desa di Kabupaten Gianyar.

Budaya organisasi yang baik menjadi penentu dari (1) tata kelola perusahaan yang baik (2) terbentuk dan berkembangnya manajemen (3) kuatnya tanggung jawab sosial dari instansi terhadap lingkungan dan (4) semangat untuk menjaga keunggulan instansi (Moeljono, 2005). Budaya organisasi yang kuat akan memiliki pengaruh yang besar terhadap perilaku anggota-anggotanya karena kadar kebersamaan dan intensitas menciptakan suasana internal berupa kendali perilaku yang tinggi (Robbins \& Jugde, 2008). Budaya organisasi menjadi salah satu hal yang penting untuk meningkatkan kinerja karena memiliki lebih banyak pengaruh pada kinerja organisasi dengan mempengaruhi psikologis masing-masing pegawai, kelompok kerja, dan bahkan seluruh organisasi (Pirson \& Lawrence, 2010)

Penelitian Soraya (2018) yang menggunakan budaya organisasi sebagai pemoderasi mendapatkan hasil bahwa budaya organisasi memperkuat kinerja keuangan di BPD Bali, semakin kuat budaya organisasi maka semakin kuat pula kinerja keuangan organisasi tersebut. Hasil ini juga sejalan dengan penelitian yang dilakukan oleh Puspitha yang menemukan bahwa budaya organisasi memperkuat pengaruh prinsip-prinsip GCG terhadap kinerja perusahaan berbasis balance scorecard BPR di Kabupaten Badung. Dengan demikian rumusan hipotesis yang dapat dirumuskan adalah sebagai berikut.

$\mathrm{H}_{2}$ : Budaya organisasi berpengaruh positif pada kinerja keuangan Lembaga Perkreditan Desa di Kabupaten Gianyar.

\section{METODE PENELITIAN}

Penelitian ini dilakukan di Kabupatem Gianyar, yaitu pada Lembaga Perkreditan Desa di Kabupaten Gianyar. Obyek penelitian ini adalah good governance, budaya organisasi dan kinerja keuangan pada LPD di Kabupaten Gianyar. Populasi dari penelitian ini adalah seluruh karyawan penyelenggara LPD di Kabupaten Gianyar. Terdapat 270 LPD di Kabupaten Gianyar. Teknik penentuan sampel dari penelitian ini adalah dengan menggunakan salah satu bagian teknik probability sampling yaitu teknik proportionate stratified random sampling dengan menggunakan rumus Slovin. Tujuan menggunakan rumus Slovin dalam 
penelitian ini adalah karena jumlah sampel penelitian harus representative agar dapat digeneralisasikan.

Adapun Rumus Slovin (1990) dalam Rahyuda (2004:45) untuk menentukan sampel adalah sebagai berikut.

$\mathrm{N}=\mathrm{N} /\left(1+\mathrm{Ne}^{2}\right)$

Dimana:

$\mathrm{n} \quad=$ Jumlah anggota sampel

$\mathrm{N} \quad=$ Jumlah anggota populasi

e $\quad=$ Nilai kritis (batas ketelitian, $(1 \%, 5 \%, 10 \%)$

$\mathrm{n} \quad \quad=\mathrm{N} /\left(1+270(0,1)^{2}\right)$

$=270 /\left(1+270(0,1)^{2}\right)$

= 72,97; dibulatkan menjadi 73 .

Sehingga jumlah sampel dalam penelitian ini seminimalnya adalah sebanyak 73 responden di LPD Kabupaten Gianyar, namun akan digenapkan menjadi sebanyak 75 responden.

Penelitian ini menggunakan beberapa uji statistik, dimulai dari uji validitas dan uji reliabilitas. Uji validitas adalah untuk mengukur sebuah instrumen dapat digunakan untuk mengukur data, jika instrumeni tersebut dapat digunakan untuk mengukur apa yang seharusnya diukur (Sugiyono, 2017). Uji reliabilitas bertujuan untuk menunjukkan bahwa instrumen dapat dipercaya sebagai alat pengumpul data. Kemudian pengujian dilanjutkan dengan uji statistik deskriptif untuk memberi gambaran atau deskripsi suatu data yang dilihat dari nilai rata-rata, standar deviasi, varian, maksimum, minimum, sum range, kurtosis dan skewness (Ghozali, 2016). Selanjutnya dilakukan uji asumsi klasik yang terdiri dari uji normalitas, uji multikolinearitas, dan uji heterokedastisitas. Setelah melakukan uji asumsi klasik, pengujian dilanjutkan dengan uji analisis regresi linear berganda digunakan untuk mengetahui pengaruh variabel bebas terhadap variabel terikat secara bersamasama ataupun secara parsial tanpa melibatkan variabel pemoderasi. Hasil dari analisis regresi linear berganda adalah berupa koefisien untuk masing-masing variabel independen (Sugiyono, 2017). Dalam penelitian ini, juga menggunakan uji koefisien determinasi, uji kelayakan model (uji F), dan uji statistik t. Koefisien determinasi (R2) digunakan untuk mengukur seberapa jauh kemampuan model dalam menerangkan variabel dependen. Nilai koefisien variabel independen dalam menjelaskan variasi variabel dependen sangat terbatas. Uji kelayakan model digunakan untuk melihat kelayakan model penelitian, yakni apakah model penelitian layak atau tidak untuk digunakan sebagai model regresi. Uji statistik $\mathrm{t}$ menunjukkan seberapa jauh pengaruh satu variabel bebas secara individual dalam menerangkan variasi variabel terikat (Ghozali, 2016).

Persamaan regresi linier berganda dalam penelitian ini adalah sebagai berikut.

$\mathrm{Y}=\mathrm{a}+\mathrm{bX}+\varepsilon$

Dimana:

$\mathrm{Y} \quad=$ Variabel terikat (kinerja keuangan)

a $\quad=$ konstanta

$\mathrm{b} \quad=$ koefisien regresi $\mathrm{x}$

$\mathrm{X} \quad=$ Variabel bebas (good corporate governance) 


\section{HASIL DAN PEMBAHASAN}

Berdasarkan data pada Tabel 1, bahwa variabel Good Governance memiliki nilai minimum sebesar 40,14 dan nilai maksimum sebesar 65,62 dengan nilai rata-rata sebesar 52,7620 serta standar deviasi atau penyimpangan rata-rata sebesar 6,85399. Variabel Budaya Organisasi memiliki nilai minimum sebesar 33,40 dan nilai maksimum sebesar 67,54 dengan nilai rata-rata sebesar 50,9369 serta standar deviasi atau penyimpangan rata-rata sebesar 8,40275. Variabel Kinerja Keuangan memiliki nilai minimum sebesar 0,095 dan nilai maksimum sebesar 0,180 dengan nilai rata-rata sebesar 0,12767 serta standar deviasi atau penyimpangan rata-rata sebesar 0,016960. Hasil analisis deskriptif disajikan pada Table 1.

Tabel 1. Hasil Analisis Deskriptif

\begin{tabular}{lccccc}
\hline & N & Minimum & Maximum & Mean & $\begin{array}{l}\text { Std. } \\
\text { Deviation }\end{array}$ \\
\hline Good Governance & 75 & 40,14 & 65,62 & 52,7620 & 6,85399 \\
Budaya Organisasi & 75 & 33,40 & 67,54 & 50,9369 & 8,40275 \\
Kinerja Keuangan & 75 & 0,095 & 0,180 & 0,12767 & 0,01696 \\
Valid N (listwise) & 75 & & & & \\
\hline
\end{tabular}

Sumber: Data Penelitian, 2020

Untuk menguji apakah data yang digunakan normal atau tidak dapat dilakukan dengan menggunakan uji Kolmogorov-Smirnov dengan melihat nilai Asymp. Sig. (2-tailed). Jika nilai Asymp. Sig. (2-tailed) lebih besar taraf signifikansi yang ditetapkan yaitu 5 persen $(0,05)$, maka data tersebut telah berdistribusi normal. Berdasarkan hasil analisis, diperoleh hasil seluruh variabel di atas 0,05 yang artinya data berdistribusi normal. Hasil uji normalitas dapat dilihat pada Tabel 2.

\section{Tabel 2. Hasil Uji Normalitas Data}

\begin{tabular}{llll}
\hline Variabel & Kolmogorov-Smirnov & Sig. & Kesimpulan \\
\hline Good Governance $(\mathrm{X} 1)$ & 0,703 & 0,706 & Data Normal \\
Budaya Organisasi $(\mathrm{X} 2)$ & 0,600 & 0,864 & Data Normal \\
Kinerja Keuangan $(\mathrm{Y})$ & 1,115 & 0,166 & Data Normal \\
\hline
\end{tabular}

Sumber: Data Penelitian, 2020

Untuk mendeteksi ada atau tidaknya multikolinearitas dalam model regresi yaitu mempunyai angka Tolerance $>0,10$ atau mempunyai nilai VIF $<10$. Berdasarkan hasil analisis, dapat dilihat bahwa koefisien Tolerance kedua variabel lebih besar dari 0,10 yaitu serta nilai VIF yang lebih kecil dari 10. Hasil ini mengindikasikan bahwa tidak terdapat gejala multikolinear dari model regresi yang dibuat. Hasil uji multikolinieritas dapat dilihat pada Tabel 3.

Tabel 3. Hasil Uji Multikolinieritas

\begin{tabular}{|c|c|c|c|}
\hline Variabel & Tolerance & VIF & Kesimpulan \\
\hline Good Governance (X1) & 0,901 & 1,110 & $\begin{array}{l}\text { Tidak terjadi } \\
\text { multikolinearitas }\end{array}$ \\
\hline Budaya Organisasi (X2) & 0,901 & 1,110 & $\begin{array}{l}\text { Tidak terjadi } \\
\text { multikolinearitas }\end{array}$ \\
\hline
\end{tabular}

Sumber: Data Penelitian, 2020

Untuk mengetahui ada atau tidaknya heteroskedastisitas yaitu dengan melakukan Uji Glejser dengan meregresi nilai absolut terhadap variabel 
independen, dengan ketentuan jika nilai signifikan diatas 0,05 maka memiliki arti tidak terjadi heteroskedastisitas. Hasil uji menunjukkan nilai signifikansi lebih dari 0,05 yang artinya model regresi bebas dari gejala heteroskedastisitas. Hasil uji heterokedastisitas dilihat pada Tabel 4 .

Tabel 4. Hasil Uji Heterokedastisitas

\begin{tabular}{lll}
\hline Variabel & Sig. & Kesimpulan \\
\hline Good Governance $(\mathrm{X} 1)$ & 0,278 & Tidak terjadi heteroskedastisitas \\
Budaya Organisasi (X2) & 0,061 & Tidak terjadi heteroskedastisitas \\
\hline
\end{tabular}

Analisis regresi linear berganda digunakan untuk mengukur antara variabel bebas terhadap variabel terikat. Hasil uji Analisis Regresi Linear Berganda dapat dilihat pada Tabel 5.

Tabel 5. Hasil Uji Analisis Regresi Linear Berganda

\begin{tabular}{llllll}
\hline Model & \multicolumn{2}{l}{ Unstandardized Coefficients } & $\begin{array}{l}\text { Standardized } \\
\text { Coefficients }\end{array}$ & $\mathrm{t}$ & Sig. \\
\cline { 2 - 4 } & $\mathrm{B}$ & Std. Error & Beta & \\
\hline (Constant) & 0,126 & 0,016 & & 8,075 &, 000 \\
Good Governance & 0,001 & 0,000 & 0,326 & 2,908 &, 005 \\
Budaya Organisasi & 0,001 & 0,000 & 0,400 & 3,566 &, 001 \\
\hline
\end{tabular}

Sumber: Data Penelitian, 2020

Berdasarkan perhitungan analisis regresi linear berganda, maka didapatkan hasil persamaan regresi sebagai berikut.

$$
\mathrm{Y}=0,126+0,001 \mathrm{X}_{1}+0,001 \mathrm{X}_{2}
$$

Berdasarkan Tabel 6, nilai $\mathrm{R}$ square sebesar 0,584 mengartikan bahwa sebesar 58,4\% variable kinerja keuangan dipengaruhi oleh good governance dan budaya organisasi, sedangkan sisanya sebesar $41,6 \%$ dipengaruhi oleh faktor lain yang tidak diteliti.

\section{Tabel 6. Hasil Koefisien Determinasi}

\begin{tabular}{llllll}
\hline Model & $\mathrm{R}$ & $\mathrm{R}$ Square & $\begin{array}{l}\text { Adjusted } \\
\text { Square }\end{array}$ & $\mathrm{R}$ & $\begin{array}{l}\text { Std. Error of the } \\
\text { Estimate }\end{array}$ \\
\hline 1 & $0,429 \mathrm{a}$ & 0,584 & 0,562 & 0,015529
\end{tabular}

a. Predictors: (Constant), Budaya Organisasi, Good Governance

Sumber: Data Penelitian, 2020

Uji kelayakan model atau uji $\mathrm{F}$ adalah untuk melihat bagaimana pengaruh semua variabel bebasnya secara bersama-sama terhadap variabel terikat. Hasil uji kelayakan model atau uji F dapat dilihat pada Tabel 7.

Tabel 7. Hasil Uji F

\begin{tabular}{lllllll}
\hline $\begin{array}{l}\text { ANOVA } \\
\text { Model }\end{array}$ & Sum of Squares & df & Mean Square & F & Sig. \\
\hline 1 & Regression & 0,004 & 2 & 0,002 & 2,128 &, $005^{\mathrm{b}}$ \\
& Residual & 0,017 & 72 & 0,000 & & \\
& Total & 0,021 & 74 & & & \\
\hline
\end{tabular}

Sumber: Data Penelitian, 2020

Berdasarkan perhitungan, diperoleh nilai $F_{\text {hitung }}$ sebesar 2,128. Sedangkan nilai $\mathrm{F}_{\text {tabel }}$ dihitung dengan menggunakan rumus $=\mathrm{F}_{\{\alpha,(\mathrm{k}-\mathrm{l}),(\mathrm{n}-\mathrm{k})\}}$ sehingga $\mathrm{f}_{\text {tabel }}=$ $\mathrm{f}_{\{0,05,(2),(72)\},}$, berdasarkan tabel distribusi $\mathrm{F}$ maka besarnya $\mathrm{f}_{\text {tabel }}$ adalah 3,13 . Hasil dari uji $\mathrm{F}$ diperoleh $\mathrm{f}_{\text {hitung }}<\mathrm{f}_{\text {tabel }}=2,128<3,13$, sehinggga $\mathrm{H}_{0}$ ditolak dan Ha diterima. Hasil ini berarti variabel bebas yaitu good governance (X1) dan budaya 
organisasi (X2) berpengaruh signifikan secara serempak atau bersama-sama terhadap variabel terikat yaitu kinerja keuangan $(\mathrm{Y})$.

Uji t digunakan untuk menguji hipotesis penelitian. Hasil uji t dapat dilihat dari Tabel 8.

Tabel 8. Hasil Uji t

\begin{tabular}{lllllr}
\hline \multirow{2}{*}{ Model } & \multicolumn{2}{l}{ Unstandardized Coefficients } & $\begin{array}{l}\text { Standardized } \\
\text { Coefficients }\end{array}$ & $\mathrm{t}$ & \multirow{2}{*}{ Sig. } \\
\cline { 2 - 4 } & $\mathrm{B}$ & Std. Error & Beta & \\
\hline (Constant) & 0,126 & 0,016 & & 8,075 &, 000 \\
Good Governance & 0,001 & 0,000 & 0,326 & 2,908 &, 005 \\
Budaya Organisasi & 0,001 & 0,000 & 0,400 & 3,566 &, 001 \\
\hline
\end{tabular}

Sumber: Data Penelitian, 2020

Berdasarkan hasil perhitungan, diperoleh nilai Sig. sebesar 0,005 dan nilai $t_{\text {hitung }}$ sebesar 2,908. Sedangkan nilai $t_{\text {tabel }}$ dihitung menggunakan tabel $t$ dengan $\alpha$ (level of significant) $=0,05$ dan $\mathrm{df}($ degree of freedom $)=\mathrm{n}-3=75-3=72$ sehingga didapatkan nilai $t_{\text {tabel }}$ sebesar 1,993 . Hasil dari uji $t$ ini yaitu $t_{\text {hitung }}$ lebih besar dari $t_{\text {tabel }}(2,908>1,993)$, artinya $\mathrm{H}_{0}$ ditolak dan Ha diterima. Sehingga keputusannya adalah terdapat pengaruh positif dan signifikan antara good governance dengan kinerja keuangan.

Berdasarkan hasil perhitungan, diperoleh nilai Sig. sebesar 0,001 dan nilai $t_{\text {hitung }}$ sebesar 3,566. Sedangkan nilai $t_{\text {tabel }}$ dihitung menggunakan tabel $t$ dengan $a$ (level of significant $)=0,05 \mathrm{dan} \mathrm{df}($ degree of freedom $)=\mathrm{n}-3=75-3=72$ sehingga didapatkan nilai $t_{\text {tabel }}$ sebesar 1,993 . Hasil dari uji $t$ ini yaitu $t_{\text {hitung }}$ lebih besar dari $t_{\text {tabel }}(3,566>1,993)$, artinya H0 ditolak dan Ha diterima. Sehingga keputusannya adalah terdapat pengaruh positif dan signifikan antara budaya organisasi dengan kinerja keuangan.

Berdasarkan hasil penelitian menunjukkan bahwa good governance berpengaruh positif pada kinerja keuangan sehingga hipotesis pertama dalam penelitian ini diterima. Hasil dalam penelitian ini mendukung teori keagenan dimana terdapat asimetri informasi antara manajer dan pemilik (pemegang saham) sehingga teori agensi menjadi dasar pemikiran bahwa kinerja keuangan perusahaan yang lebih baik dapat dicapai karena adanya good corporate governance (Haat, et al. 2008). Frederickson (1997:25) memberikan pengertian mengenai good governance dimana suatu keahlian atau spesialisasi, layanan pada warga sipil, pembangunan lembaga, ilmu administrasi, dan asumsi dari kepentingan umum secara kolektif. LPD yang memiliki good governance yang baik akan meningkatkan kinerja keuangan LPD tersebut.

Krismaya (2014) sebelumnya pada penelitiannya mengenai pengaruh prinsip good governance pada kinerja keuangan di LPD Kabupaten Gianyar menyatakan bahwa terdapat pengaruh yang signifikan antara penerapan prinsip good governance pada kinerja keuangan di LPD Kabupaten Gianyar dimana terdapat korelasi yang sangat kuat antara penerapan prinsip good governance pada kinerja keuangan LPD, apabila terjadi satu kenaikan atau penurunan tingkat good governance maka akan mempengaruhi pula kinerja keuangan LPD tersebut.

Kita (2017) dalam penelitiannya mengenai pengaruh good governance terhadap kinerja aparatur di Kabupaten Klungkung menemukan hasil bahwa 
good governance berpengaruh positif terhadap kinerja aparatur. Berdasarkan pernyataan sebelumnya dan ditambah dengan hasil penelitian ini mengungkapkan bahwa apabila semakin baik penerapan good governance maka semakin baik pula kinerja pemerintahan tersebut.

Menurut Soraya (2018) menyebutkan dalam penelitiannya tentang budaya organisasi sebagai pemoderasi hubungan good governnance dan kinerja keuangan, bahwa terdapat pengaruh positif dan signifikan antara good governance terhadap kinerja keuangan di Bank BPD Bali. Semakin baik penerapan good governance dalam suatu perusahaan maka akan semakin baik pula kinerja keuangan dalam perusahaan tersebut.

Berdasarkan hasil penelitian menunjukkan bahwa budaya organisasi berpengaruh positiff pada kinerja keuangan sehingga hipotesis kedua dalam penelitian ini diterima. Budaya merupakan salah satu dasar dari asumsi untuk mempelajari dan memecahkan suatu masalah yang ada didalam suatu organisasi. Suatu organisasi termasuk birokrasi pemerintahan didirikan sebagai suatu wadah untuk mencapai suatu atau beberapa tujuan. Organisasi tersebut harus mengelola berbagai dan rangkaian kegiatan yang diarahkan menuju tercapainya tujuan organisasi. Pelaksanakan rangkaian kegiatan dalam organisasi dilakukan oleh manusia (humanbeing) yang bertindak sebagai aktor atau peserta dalam organisasi yang bersangkutan, maka dengan sendirinya kinerja (performance) organisasi yang bersangkutan banyak tergantung pada perilaku manusia yang terdapat dalam organisasi tersebut.

Budaya organisasi merupakan nilai-nilai yang menjadi pedoman sumber daya manusia untuk menghadapi permasalahan eksternal dan usaha penyesuaian integrasi ke dalam organisasi sehingga masing-masing anggota organisasi harus memahami nilai-nilai yang ada dan bagaimana mereka bertingkah laku atau berprilaku. Jadi dengan demikian LPD perlu meningkatkan nilai-nilai budaya organisasi agar dapat diwujudkannya kinerja yang lebih baik di dalam LPD.

Hasil penelitian ini dapat membuktikan teori yang digunakan dalam penelitian ini yaitu teori keagenan. Selain itu, penelitian ini juga menambah referensi, informasi, wawasan, dan memberikan pemahaman yang lebih luas berkaitan dengan pengaruh good governance dan budaya organisasi pada kinerja keuangan.

Hasil penelitian ini dapat menjadi pertimbangan aparatur di dalam LPD bahwa pentingnya penerapan good governance dan budaya organisasi pada kinerja keuangan. Berdasarkan hasil pembahasan, maka kinerja keuangan akan meningkat dengan menerapkan good governance.

\section{SIMPULAN}

Good governance berpengaruh positif pada kinerja keuangan lembaga perkreditan desa di Kabupaten Gianyar. Hal ini berarti semakin baik penerapan good governance maka semakin meningkat pula kinerja keuangan LPD tersebut.

Budaya organisasi berpengaruh positif pada kinerja keuangan lembaga perkreditan desa di Kabupaten Gianyar. Hal ini berarti budaya organisasi akan meningkatkan kinerja keuangan LPD tersebut. 
Aparatur penyelenggara LPD khususnya di Kabupaten Gianyar diharapkan dapat menerapkan good governance dan budaya organisasi dengan lebih baik lagi agar dapat meningkatkan kinerja keuangan yang lebih baik pula.

Penelitian selanjutnya disarankan untuk menggunakan sampel yang lebih luas, misal seluruh LPD yang ada di Kabupaten Gianyar, maupun seluruh LPD di Bali.

Besarnya nilai $R$ Square dalam penelitian ini sebesar 0,584 mengartikan bahwa sebesar $58,4 \%$ variasi kinerja keuangan dipengaruhi oleh good governance dan budaya organisasi, sedangkan sisanya sebesar $41,6 \%$ masih dipengaruhi oleh faktor lain yang tidak diteliti dalam penelitiannya. Penelitian selanjutnya disarankan untuk menambah variabel bebas lainnya yang diduga dapat berpengaruh pada kinerja keuangan LPD seperti gaya kepemimpinan, partisipasi anggaran, komitmen organisasi, kompetensi.

\section{REFERENSI}

Adebayo, M., Bakare, I. A. O., Babatunde, Y., \& Ishmael, O. (2014). Good Corporate Governance and Organisational Performance: An Empirical Analysis. International Journal of Humanities and Social Science, 4(7), 170-178.

Frederickson, H. G. (1997). The Spirit of Public Administration. Jossey-Bass Publishers.

Ghozali, I. (2016). Aplikasi Analisis Mulivariate dengan Program IBM SPSS 21 Update PLS Regresi (Edisi Kede). Universitas Diponegoro.

Gunawan, R. M., Effendie, B., \& Budiarjo, D. (2014). The Influence of Good Corporate Governance, Ownership Structure and Bank Size to the Bank Performance and Company Value in Banking Industry in Indonesia (A Study on Go-Public National Private Banking Corporation with Foreign Capital Investment During the. European Journal of Business and Management, 5(24), 9-19.

Ingdanata, D. P. (2018). Pengaruh Good Governance dan Love of Money Pada Kinerja Keuangan Bank Perkreditan Rakyat di Kota Denpasar. E-Jurnal Akuntansi Universitas Udayana, 22(1), 381-407.

Kita, N. L. M. N. S. (2017). Pengaruh Partisipasi Anggaran, Komitmen Organisasi, Budaya Organisasi dan Kompetensi Terhadap Kinerja Aparatur Penyelenggara Pemerintahan Desa di Kabupaten Klungkung. Udayana.

Mahaendrayasa, P. K. A., \& Putri, I. G. A. A. D. (2017). Pengaruh Prinsip-Prinsip Good Corporate Governance Terhadap Kinerja Keuangan Lembaga Perkreditan Desa (LPD) di Kota Denpasar. E-Jurnal Akuntansi Universitas Udayana, 21(2), 970-995.

Moeljono, D. (2005). Budaya Organisasi dalam Tantangan (PT. Elex M).

Pirson, M. A., \& Lawrence, P. R. (2010). Humanism in Business-Towards a Paradigm Shift? Journal of Business Ethics, 93, 553-565.

Pradnyaswari, D. A. (2016). Pengaruh Penerapan Prinsip-Prinsip Good Corporate Governance Pada Kinerja Keuangan Koperasi di Kabupaten Klungkung. E-Jurnal Akuntansi Universitas Udayana, 14((2)), 1069-1091.

Puspitha, M. Y., \& Sujana, I. K. (2016). Budaya Organisasi Sebagai Pemoderasi Pengaruh Prinsip Good Corporate Governance Pada Kinerja Perusahaan Berbasis Balance Scorecard. , 14(),. E-Jurnal Akuntansi Universitas Udayana, 
14(3), 1978-2012.

Robbins, S. P., \& Jugde, T. A. (2008). Perilaku Organisasi. Salemba Empat.

Soraya, B. E., \& Suardana, K. A. (2018). Budaya Organisasi Sebagai Pemoderasi Pengaruh Good Corporate Governance pada Kinerja Keuangan Bank Pembangunan Daerah Bali Fakultas Ekonomi dan Bisnis Universitas Udayana (Unud), Bali, Indonesia Fakultas Ekonomi dan Bisnis Universitas Udayana ( Unud ),. 23(3), 2414-2443.

Sugiyono. (2017). Metode Penelitian Kuantitatif, Kualitatif, dan RED. Alfabeta. 